\title{
Het GLB na 2020: mogelijkheden voor biodi- versiteit, bodem en klimaat
}

Jan Willem Erisman, LB|

Anne van Doorn, WENR

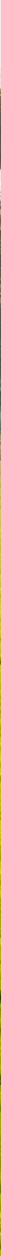


(C) 2018 Louis Bolk Instituut

Het GLB na 2020: mogelijkheden voor biodiversiteit, bodem en klimaat

Prof. dr. ing. J.W. Erisman', dr.ir. A.M. van Doorn²

1 Louis Bolk Instituut 2 Wageningen Environmental Research

Publicatienummer 2018-025 LbP

WENR rapport 2908

31 pagina's

Deze publicatie is beschikbaar via www.louisbolk.nl/publicaties en www.wur.nl/environmental-research

www.louisbolk.nl

info@lovisbolk.nl

T 0343523860

Kosterijland 3-5

3981 AJ Bunnik

@LouisBolk

Louis Bolk Instituut: Onderzoek en advies ter bevordering van duurzame landbouw, voeding en gezondheid 


\section{Voorwoord}

De voorstellen die de Europese Commissie dit voorjaar presenteerde voor het nieuwe Gemeenschappelijk Landbouwbeleid (GLB) zijn belangrijk voor de Nederlandse landbouwsector. De huidige beleidsronde loopt van 2014 tot 2020 en vanaf 2021 zal het nieuwe beleid moeten ingaan. Het GLB is een belangrijke bron van subsidie voor zaken als innovatie, klimaat, en agrarisch natuur- en landschapsbeheer. Daarmee is ook wel duidelijk dat wijzigingen in de grondslag van het GLB, of wijzigingen in de criteria voor vitbetaling, direct effecten kunnen hebben op innovatie, biodiversiteit of agrarisch natuurbeheer. Een deel van die effecten zal rechtstreeks voortkomen vanuit de nieuwe Europese afspraken. Een ander deel zal afhankelijk zijn van de Nederlandse invulling van het GLB.

De vaste commissie voor Landbouw, Natuur en Voedselkwaliteit van de Tweede Kamer der Staten-Generaal heeft de behoefte aan een impact assessment naar de effecten van de Europese voorstellen voor een nieuw GLB op bodemkwaliteit, biodiversiteit, innovatie, klimaat en agrarisch natuurbeheer. De onderzoeksvraag luidt als volgt: Welke impact hebben de GLB-voorstellen van de Europese Commissie op bodemkwaliteit, biodiversiteit, innovatie, klimaat en agrarisch natuurbeheer in Nederland? Hoe beïnvloeden nog te maken keuzes voor nationale invulling deze impact?

Het Louis Bolk Instituut heeft samen met Wageningen Environmental Research op basis van de informatie die beschikbaar is, de kennis bij beide instituten en een expert judgement een analyse gemaakt van de keuzemogelijkheden die lidstaten hebben om het GLB meer te richten op bodem, biodiversiteit en klimaat en welke bijdrage het GLB dan kan leveren aan het halen van doelen. Wij hopen met deze assessment een nuttige bijdrage te leveren aan een zodanige invulling van het GLB de komende jaren dat zowel de boer als ook onze leefomgeving er ruim voldoende baat bij zal hebben. 



\section{Inhoud}

$\begin{array}{lc}\text { Samenvatting } & 6\end{array}$

$\begin{array}{lr}\text { Summary } & 7\end{array}$

$\begin{array}{llr}1 & \text { Inleiding en achtergrond } & 8\end{array}$

2 De opdracht en de gekozen aanpak $\quad 10$

2.1 Uitgangspunten en beperkingen 11

$\begin{array}{ll}2.2 \text { Keuzemogelijkheden voor lidstaten } & 12\end{array}$

3 Doelen 15

4 Invulling van keuzemogelijkheden: overwegingen, aannames en scenario's 17

$\begin{array}{lll}4.1 & \text { Versterkte conditionaliteit } & 18\end{array}$

$\begin{array}{ll}4.2 \text { Eco-schema's } & 20\end{array}$

5 Methode voor het bepalen van de bijdrage aan doelen 22

6 Score van de eco-schema scenario's op effecten voor klimaat, biodiversiteit en $\begin{array}{ll}\text { bodem } & 24\end{array}$

6.1 Potentieel haalbare resultaten $\quad 24$

6.2 Scores binnen beschikbare budget 24

6.3 Het bredere perspectief 25

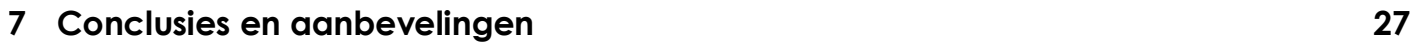

$\begin{array}{lr}\text { Literatuur } & 29\end{array}$

Bijlage 1: Beschrijving van de mogelijke opties $\quad 30$ 


\section{Samenvatting}

De voorstellen van de Europese Commissie voor het nieuwe Gemeenschappelijk Landbouwbeleid (GLB) zijn belangrijk voor de Nederlandse landbouwsector omdat zij inkomenssteun oplevert en een mogelijkheid biedt om verduurzaming van de landbouw te stimuleren. De Europese Commissie stelt als doelen van het nieuwe GLB:

- Het bevorderen van een slimme en veerkrachtige landbouwsector;

- Een wezenlijke bijdrage leveren aan Europese doelstellingen t.a.v. klimaat en natuurlijke leefomgeving;

- Het versterken van de sociaaleconomische structuur van plattelandsgebieden. In het nieuwe voorstel is er veel ruimte voor lidstaten om gericht te werken aan regionale doelen. Ten eerste door minimale voorwaarden te stellen aan inkomenssteun t.a.v. een goede landbouw en milieu conditie m.b.t. klimaat, bodem, water en biodiversiteit, de versterkte conditionaliteit. Daarbovenop kunnen landbouwers worden beloond als ze maatregelen nemen die verder gaan dan de verplichte vereisten in verband milieu- of klimaatbeleid. Hiervoor kan iedere lidstaat zogenaamde eco-schema's ontwikkelen. Tenslotte kunnen de agro-milieu en klimaat maatregelen van de 2e pijler ook nog ingezet worden In dit rapport wordt een overzicht gegeven van wat de doelstellingen en keuzemogelijkheden zijn t.a.v. de versterkte conditionaliteit en de ecoschema's. Verder wordt er een overzicht gegeven van verschillende maatregelen en opties passend bij de vier thema's van de Commissie: klimaat, water, bodem en biodiversiteit en landschap. Vervolgens is een methodiek ontwikkeld om dit soort maatregelen en opties te beoordelen op hun bijdrage aan het realiseren van beleidsdoelen die voor klimaat, biodiversiteit en bodem in 2030. Voor het eco-schema is aangesloten bij de scenario's ontwikkeld door WUR (Terluin et al 2018). Hieruit is een overzicht gekomen van de budgetverdeling, hectare toeslagen en deelnemingspercentages van vier scenario's: het basis-plus, het eco-schema licht, het ecoschema zwaar en kringlooplandbouw scenario. Op basis van de resultaten wordt een advies gegeven over de mogelijkheden om het GLB in te vullen vanuit het perspectief voor biodiversiteit, bodemkwaliteit en klimaat.

$E r$ is veel ruimte voor lidstaten hun eigen ambitie te kiezen, budgetten te verdelen over de verschillende instrumenten en maatregelen en voorwaarden te bepalen. De viteindelijke bijdrage van het GLB aan bodem-, klimaat- en biodiversiteitsdoelen is het resultaat van een samenspel tussen voorwaarden en maatregelen, de hectare toeslag en aantal deelnemende boeren. Het verdient een zorgvuldige afweging welke voorwaarden voor versterkte conditionaliteit gelden en welke prestaties betaald worden via de eco-schema's.

Wij hebben gekozen om voor versterkte conditionaliteit t.a.v. bodemkwaliteit en klimaat zoveel mogelijk boeren mee te laten doen. Het eco-schema - licht en het kringloopscenario komen het beste uit de bus, omdat daarmee de stappen richting realisatie doelen 2030 naar verwachting het grootst zullen zijn. Biodiversiteit blijft iets achter, maar door via de versterkte conditionaliteit te zorgen voor een goede basiskwaliteit kunnen via de pijler II speci- 
fieke maatregelen voor specifieke soorten genomen worden. . Passend binnen het Nederlandse budget is het mogelijk om bij de juiste keuze naar zo'n $20 \%$ doelrealisatie te gaan. Dit is meer dan een verdubbeling t.o.v. het huidige GLB en daarmee worden stappen gezet richting vergroeningsresultaat. GLB is daarmee weliswaar een belangrijk beleidsspoor om bij te dragen aan klimaat-, bodem en biodiversiteitsdoelen, maar het GLB alleen niet voldoende is om deze doelen ook te realiseren.

De resultaten van deze studie laten zien wat mogelijkheden zijn voor de verschillende keuzes ten aanzien van toeslagen en maatregelen indien er vanuit doelen wordt geredeneerd. De methode is toepasbaar ook bij andere keuzes of invullingen. Van belang is om de maatregelen te richten op het perceelsniveau voor de doelen klimaat en bodem (inclusief water en basis biodiversiteit) en voor de maatregelen rond het perceel voor biodiversiteit en specifieke soorten. Inzet zou in ieder geval gericht moeten worden op integrale maatregelen of zorgen dat maatregelen optellen op alle aspecten. Hiervoor zouden geëigende instrumenten als de Kringloopwijzer en de Biodiversiteitsmonitor vitstekende hulpmiddelen kunnen zijn voor de kwantificering en sturing.

\section{Summary}

The proposal of the European Commission for the new Common Agricultural Policy (CAP) is important for the Dutch agricultural sector because it provides income support and offers an opportunity to stimulate the sustainability of agriculture. The European Commission sets as objectives of the new CAP:

- Promoting a smart and resilient agricultural sector;

- Make a substantial contribution to European objectives regarding climate and environment;

- Strengthening the socio-economic structure of rural areas.

The new proposal leaves room for Member States to work specifically on regional targets. Firstly, by setting minimum conditions for income support for good agriculture and environmental condition regarding climate, soil, water and biodiversity, the enhanced conditionality. In addition, farmers can be rewarded if they take measures that go beyond the mandatory environmental or climate policy requirements. For this purpose, each member state can develop so-called ecoschemes. Finally, the agro-environmental and climate measures of the 2nd pillar can also be used.

This report provides an overview of what the objectives and options for choice are in relation to the enhanced conditionality and the ecoschemes. Furthermore, an overview is given of various measures and options that fit the four themes of the Commission: climate, water, soil and biodiversity and landscape. Subsequently, a methodology has been developed to assess these types of measures and options on their contribution to the realization of policy objectives for climate, biodiversity and soil quality in 2030. 


\section{Inleiding en achtergrond}

Op 1 juni 2018 heeft de Europese Commissie de wetsvoorstellen voor het nieuwe GLB na 2020 gepresenteerd. Het gaat om drie verordeningen: de eerste is overkoepelend en biedt een kader voor de strategische GLB plannen die lidstaten moeten maken met daarin speciale aandacht voor ambities ten aanzien van leefomgeving en klimaat. De twee andere verordeningen geven invulling aan de eerste en gaan over de financiering van het GLB en over de marktordening. In de voorstellen blijft de oude betalingsstructuur van de le pijler voor directe inkomenssteun en marktordening en de $2^{e}$ pijler voor plattelandsontwikkeling bestaan, en continueert de herverdeling van het budget tussen en binnen lidstaten (interne en externe convergentie). De directe betalingen blijven, maar er komt meer flexibiliteit \& subsidiariteit, waarbij de EC voorstelt dat de toekenning van inkomenssteun aan boeren zal afhangen van hun inzet voor publieke diensten op het gebied van milieu, natuur en klimaat. Maar de precieze inhoud moet door de lidstaten verder in detail worden vitgewerkt.

Het ziet er naar vit dat er na 2020 5\% minder budget voor GLB beschikbaar is met een totaalbedrag van 365 miljard $€$. Nederland zal vanaf 2019 een gelijke betaling hanteren voor alle hectaretoeslagen.

In de voorstellen stelt de EC dat de belangrijkste doelstellingen van het toekomstige GLB moeten zijn:

- Het bevorderen van een slimme en veerkrachtige landbouwsector;

- Een wezenlijke bijdrage leveren aan Europese doelstellingen t.a.v. klimaat en natuurlijke leefomgeving;

- Het versterken van de sociaaleconomische structuur van plattelandsgebieden.

De EC wil dat het nieuwe GLB een grotere ambitie heeft op het vlak van de natuurlijke leefomgeving, klimaat en biodiversiteit. Het is daarnaast de bedoeling dat het GLB na 2020 de nadruk niet op regels en handhaving komt te liggen, maar op monitoring en beloning van concrete resultaten. De EC wil dan ook de "one size fits all"-benadering loslaten en toewerken naar een meer op maat gemaakte aanpak. Lidstaten krijgen daarom meer vrijheid om te beslissen wat de beste manier is om de doelstellingen te bereiken en tegelijkertijd in te spelen op de specifieke behoeften van boeren en het platteland. Daarom moeten lidstaten op basis van een beschrijving van de huidige situatie, met de sterke en zwakke punten, de kansen en bedreigingen voor voedsel, landbouw, natuur en het platteland (een zogenaamde SWOT-analyse) een strategisch plan voor het GLB opstellen. In dit plan wordt beschreven hoe het aan de algemene doelstellingen van het GLB wil voldoen, vertaald naar de specifieke situaties van het land. Elke lidstaat bepaalt zo de nationale strategie en legt uit hoe maatregelen en interventies van beide pijlers zullen bijdragen aan het bereiken van de doelstellingen. 


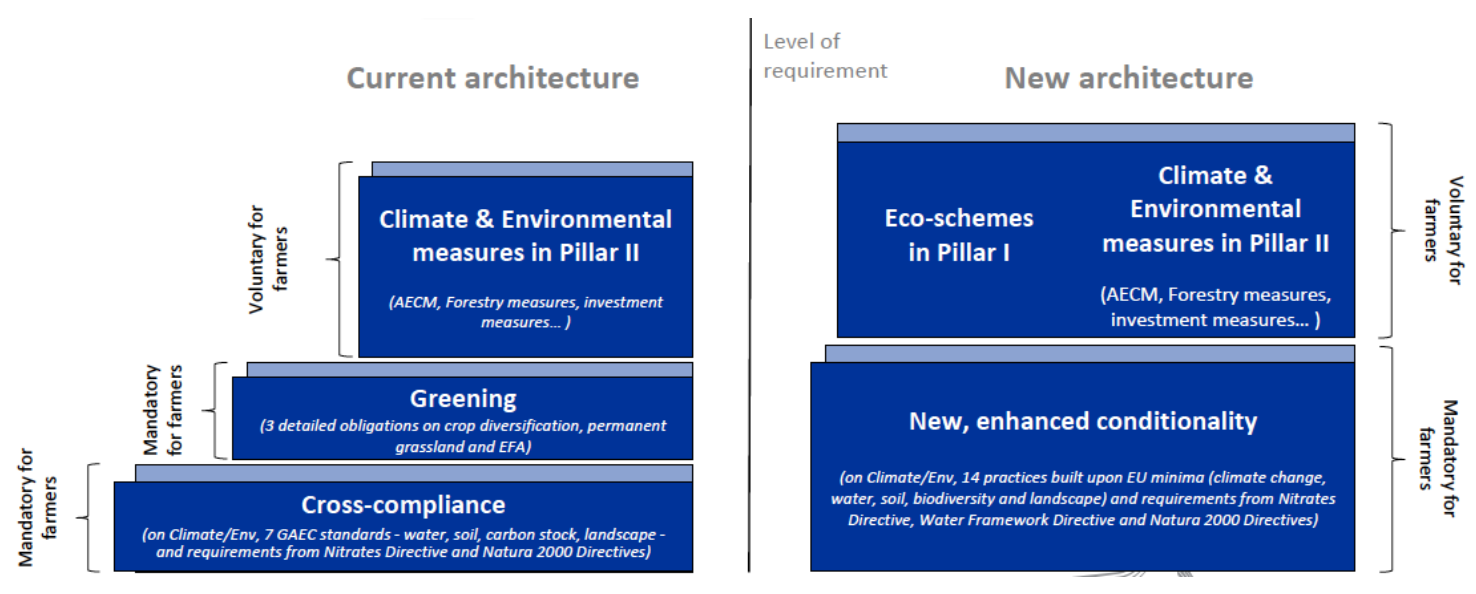

Figuur 1. De architectuur voor vergroening in het huidige GLB (links) en die in de wetsvoorstellen voor GLB na 2020 (rechts)

Om het GLB meer te richten op doelen voor klimaat en natuurlijke leefomgeving zijn drie elementen uit de voorstellen met name van belang:

- Cross Compliance en de vergroeningsmaatregelen worden vervangen door een zogenaamde versterkte conditionaliteit voor milieu en klimaat (enhanced conditionality). Deze bestaat uit de vigerende wet- en regelgeving en een aantal maatregelen die gelden als minimale milieurandvoorwaarden voor boeren die geld ontvangen vanuit het GLB (zowel premies en betalingen vanuit de 1 e en/of de 2 e pijler). Oftewel: elke ontvanger van GLB-betalingen moet voldoen aan deze voorwaarden. Verplichte maatregelen zijn onder andere (zie Tabel 1):

- behoud van koolstofrijke bodems door bescherming van wetlands en veengebieden

- verplichte tool voor nutriëntenbeheer voor de verbetering van de waterkwaliteit en vermindering van stikstof-emissies

- gewasrotatie in plaats van gewasdiversificatie.

- Bestemmen van een bepaald percentage voor niet-productieve elementen ter bevordering van biodiversiteit.

De maatregelen kunnen per lidstaat gespecificeerd worden. Artikel 12 van EC COM 3922018 meldt hierover: 'De lidstaten stellen op nationaal of regionaal niveau de door de begunstigden na te leven minimumnormen voor een goede landbouw- en milieuconditie van de grond vast [...], en houden daarbij rekening met de specifieke kenmerken van de betrokken arealen, met inbegrip van de bodem- en klimaatgesteldheid, de bestaande landbouwsystemen, het landgebruik, de vruchtwisseling, de landbouwpraktijken en de structuur van de landbouwbedrijven'.

- In pijler I worden eco-schema geïntroduceerd, deze zijn voor lidstaten verplicht om in te voeren, maar boeren kunnen vrijwillig wel of niet voor deelname kiezen. Elke lidstaat stelt een lijst op van landbouwpraktijken die onder dit eco-scheme vallen. 
De maatregelen onder een eco-scheme moeten bovenwettelijk zijn en verder gaan dan de vereisten onder de enhanced conditionality.

- De agro-milieu-klimaat maatregelen van pijler II blijven gehandhaafd, lidstaten kunnen kiezen voor modulatie: een deel van het budget overhevelen van de le naar de 2 e pijler (of andersom), dit mag maximaal $15 \%$ van het budget beslaan. Verder moet binnen de 2 e pijler $30 \%$ van het budget naar doelen op het gebied van natuurlijke leefomgeving en klimaat.

\section{De opdracht en de gekozen aanpak}

De vaste commissie voor Landbouw, Natuur en Voedselkwaliteit van de Tweede Kamer der Staten-Generaal is geïnteresseerd in de vraag welke impact de GLB-voorstellen van de Europese Commissie hebben op bodemkwaliteit, biodiversiteit, innovatie, klimaat en agrarisch natuurbeheer in Nederland? Hoe beïnvloeden nog te maken keuzes voor nationale invulling deze impact?

Deze vraag wordt opgesplitst in de volgende deelvragen:

1. Welke elementen uit de Europese GLB-voorstellen zijn relevant voor de impact op bodemkwaliteit, biodiversiteit, innovatie, klimaat en agrarisch natuurbeheer in $\mathrm{Ne}$ derland?

2. Welke keuzes kunnen er gemaakt worden bij uitvoering van het beleid in Nederland?

3. Wat hebben dergelijke keuzes voor invloed op de ontwikkelingen in Nederland en wat zijn daarvan de effecten op bodemkwaliteit, biodiversiteit, innovatie, klimaat en agrarisch natuurbeheer in Nederland? Is er een indruk te geven van de kosten - baten verhouding bij dergelijke keuzes?

4. Hoe verschillen die effecten ten opzichte van de huidige situatie? Zijn er indicatoren waarvoor de situatie in belangrijke mate verbetert of verslechtert?

5. Met welke keuzes voor vitvoering van het Nederlands beleid kunnen de verschillen ten opzichte van de huidige situatie beperkt dan wel uitgebuit worden?

6. Welke van de mogelijke invullingen voor de Nederlandse beleidsruimte voldoet het best aan de Europese doelstellingen voor bodem, biodiversiteit, klimaat, innovatie en Agrarisch Natuurbeheer (ANLb)?

Om bovenstaande vragen te beantwoorden hebben we de volgende aanpak gekozen:

a) Op basis van de tekst van de wetsvoorstellen, is er een overzicht gemaakt van de mogelijkheden die lidstaten hebben binnen de kaders van de wetsvoorstellen om het GLB meer te richten op bodem, biodiversiteit en klimaat (beantwoording vraag 1). De studie richt zich daarbij vooral op de versterkte conditionaliteit en de ecoschema's en minder op de 2e pijler

b) We laten zien welke keuzes lidstaten kunnen maken en welke gunstig zijn voor bodem, biodiversiteit en klimaat (beantwoording vraag 2). 
c) Om inzicht te geven in mogelijk verschillende uitwerkingen van het eco-schema, sluiten we aan bij de scenario's ontwikkeld door WUR (Terluin et al 2018). Hierbij worden de budgetverdeling, hectare toeslagen en deelnemingspercentage van vier scenario's gehanteerd: het basis-plus, het eco-schema licht, het eco-schema zwaar en kringlooplandbouw scenario. De invulling van het eco-schema in termen van maatregelen is vervolgens ingevuld geredeneerd vanuit de doelen voor klimaat, bodemkwaliteit en biodiversiteit en wat redelijkerwijs tegenover de hectare-vergoeding verwacht kan worden.

d) Voor zowel de versterkte conditionaliteit als het eco-schema worden keuzemogelijkheden en opties overzichtelijk op een rij gezet. De tabel (Tabel 1) is de basis van de assessment, waarbij de reikwijdte van de te verwachten effecten wordt geschetst in termen van bodemkwaliteit, biodiversiteit en klimaat. Hierbij zijn voor de scenario's drie mogelijke invullingen gekozen. Eén die meer gericht is op klimaat, één die meer gericht is op bodemkwaliteit en één die meer gericht is op biodiversiteit. Die zullen dan in financieel opzicht niet van elkaar verschillen, maar wel in de effecten op klimaat, bodemkwaliteit en biodiversiteit (beantwoording van 3e en 4e vraag).

e) Op basis van de resultaten wordt dan vraag 5 en 6 van de opdracht beantwoorden: een advies hoe het GLB het beste ingevuld kan worden vanuit het perspectief voor biodiversiteit, bodemkwaliteit en klimaat.

\subsection{Uitgangspunten en beperkingen}

Voor de analyse die gemaakt is gelden de volgende vitgangspunten en beperkingen:

- Het GLB voorstel van de Europese Commissie kent een grote mate van vrijheid voor de lidstaten, maar vergt nadere keuzes en invulling van die lidstaten, zoals een strategisch plan, SWOT analyse en budgetverdeling en daaraan gekoppelde voorwaarden voor de versterkte conditionaliteit en eco-schema. Op dit moment ontbreekt het nog aan deze keuzes en invulling, waardoor in de aanpak eigen invulling is gegeven.

- De door de WUR ontwikkelde scenario's gaan uit van deelname boeren en inzet van middelen, los van vergroeningsdoelen. Daarom is binnen de scenario's een inschatting gemaakt van welke opties uit de eco-schema's er vanuit de hectare premie en het aantal boeren gekozen zal worden. Hierbij is gewerkt met nadruk op klimaat, bodemkwaliteit en biodiversiteit en circulariteit.

- Er is voor gekozen om een analyse te doen die in principe betrekking heeft op alle boeren in NL, in deze studie zijn dus geen gebiedsgerichte opties meegenomen. Een dergelijke aanpak bijvoorbeeld door gericht in specifieke gebieden opties voor het halen van gebiedsgerichte doelen te implementeren kan wel interessant zijn voor GLB invulling. 
- Het inschatten van de effecten betreft een 'expert judgement' en geen gedetailleerde doorrekening van de effecten. Dit is gegeven de beschikbare tijd, maar ook gegeven het ontbreken van kwantitatieve informatie, onmogelijk.

- Voor het duiden van effecten zijn we zo veel mogelijk uit gegaan van bestaande doelen voor klimaat, biodiversiteit, bodemkwaliteit, water en agrarisch natuurbeheer en geven aan hoe de scenario's bijdragen aan het verkleinen van het gat tussen de huidige situatie en het doel in 2030. De focus op deze doelen in voorliggende studie sluit overigens niet uit dat het GLB ook voor andere doelen zoals bijvoorbeeld dierenwelzijn aangewend kan worden, alleen is dat niet onderdeel van deze studie.

- De Nederlandse overheid heeft een uitgebreide reactie geschreven op het GLB voorstel'. Zo laat ze bijvoorbeeld weten dat ze voorstander is van doelgerichte betalingen in plaats van de voorgestelde versterkte conditionaliteit, of in elk geval als alternatieve optie met de mogelijkheid om verplichtingen niet individueel maar collectief of regionaal in te vullen. Met deze voorkeuren is in deze studie geen rekening gehouden en is het voorstel als zijnde onveranderd aangenomen. Dat betekent bijvoorbeeld dat ook de mogelijkheden voor een versterkte conditionaliteit in beeld worden gebracht.

- De studie richt zich op de grondgebonden landbouw, alleen de melkveehouderij en akkerbouw zijn meegenomen, deze twee sectoren ontvangen samen het grootste aandeel van het GLB-budget.

\subsection{Keuzemogelijkheden voor lidstaten}

Zoals genoemd in de inleiding kunnen via drie onderdelen van de wetsvoorstellen voorgenoemde doelen bediend worden: de versterkte conditionaliteit (voorheen cross crompliance en vergroeningsmaatregelen), de eco-schema's in de le pijler en de agro-milieu-klimaatmaatregelen van de $2^{e}$ pijler. Of en hoe de doelen via deze drie instrumenten bediend kunnen worden hangt af van de invulling door de lidstaten. Daarover is nog niets bekend, dus wordt in deze paragraaf een overzicht gegeven welke keuzes lidstaten hebben en wat dan de mogelijkheden zijn om vanuit de doelen te beredeneren op welke manier de versterkte conditionaliteit en de eco-schema's kunnen worden ingevuld.

\subsubsection{Versterkte conditionaliteit}

De Europese Commissie heeft een lijst van 10 voorwaarden voor een goede landbouw en milieu conditie (GLMC) voorgesteld, deze staan in bijlage 3 van de verordening. Tabel 1 Overzicht van de voorwaarden voor een goede landbouw en milieu conditie (GLMC), de belangrijkste doelstelling en de te verwachten keuzemogelijkheden voor lidstaten We zullen

\footnotetext{
1 https://1848.nl/static/pdf/88/fb/88fb25825d205d9974e8778177329f4fb 1840af9.pdf
} 
nu elke GLMC toelichten, het doel van de voorwaarde en de keuzemogelijkheden voor lidstaten.

De eerste drie GLMC's zijn specifiek voor klimaat doelen bedoelt. GLMC 1 is in feite één van de vergroeningsmaatregelen van de 2013-2020 periode en betreft de Instandhouding van blijvend grasland op basis van een verhouding blijvend grasland ten opzichte van het landbouwareaal. De GLMC is bedoeld als waarborg tegen omschakeling naar andere landbouwtoepassingen met het oog op het behoud van de koolstofvoorraad. Lidstaten kunnen de schaal waarop ze blijvend gras monitoren kiezen, op nationaal, regionaal of bedrijfsniveau. Nederland doet dit nu op nationaal niveau, maar kan er voor kiezen om dit op een lager schaalniveau te doen. GLMC 2 moet zorgen voor een passende bescherming van wetlands en veengebieden zodat koolstofrijke bodems beschermd worden. Lidstaten kunnen gebieden aanwijzen waar de maatregel van toepassing is en maatregelen specificeren voor passende bescherming. GLMC 3 verbiedt het verbranden van stoppels zodat organisch bodemmateriaal behouden blijft, voor zover bekend is hier geen keuzemogelijkheid voor lidstaten.

Voor bodem en waterkwaliteit zijn GLMC 4 t/m 8 van toepassing. GLMC 4 is gericht op waterkwaliteit, het schrift de aanleg van bufferstroken langs waterlopen voor en dient zo voor de bescherming van waterlopen tegen vervuiling en afvloeiing. Lidstaten kunnen specifieke voorwaarden formuleren met betrekking tot de breedte van de bufferstroken en op welke waterwegen de maatregel van toepassing is. GLMC 5 schrijft het verplichte gebruik van een landbouwbedrijfsduurzaamheidsinstrument voor nutriënten voor, zodat er wordt gestreefd naar een duurzaam beheer van nutriënten. Lidstaten kunnen bepalen welk instrument gebruikt wordt en of er voorwaarden gesteld worden aan de scores.

GLMC 6 gaat over het tegengaan van erosie en bodemdegradatie door voorwaarden te stellen aan de bodembewerking. Lidstaten kunnen de voorwaarden voor bodembewerking specificeren en de gebieden waarop maatregel van toepassing is. GLMC 7 moet landbouwbodems in de winter beschermen, dat wil zeggen dat de voorwaarde voorschrijft dat er geen kale grond in de meest gevoelige periode(n) mag voorkomen. Lidstaten kunnen bijvoorbeeld voorwaarden stellen aan het type en de duur van de winterbedekking. GLMC 8 moet zorgen voor behoud van de bodemgezondheid en vruchtbaarheid door geschikte gewasrotaties. Lidstaten kunnen de voorwaarden voor de gewasrotaties specificeren. 
Tabel 1 Overzicht van de voorwaarden voor een goede landbouw en milieu conditie (GLMC), de belangrijkste doelstelling en de te verwachten keuzemogelijkheden voor lidstaten. $\mathrm{MvH}=$ melkveehouderij en $A B=$ Akkerbouw en tuinbouw

\begin{tabular}{|c|c|c|c|}
\hline & Onderdeel & Belangrijkste doelstelling & Keuzemogelijkheden voor LS 2 \\
\hline \multirow[t]{3}{*}{ Klimaat } & $\begin{array}{l}\text { GLMC } 1 \text { Instandhouding van blij- } \\
\text { vend grasland op basis van een } \\
\text { verhouding blijvend grasland ten } \\
\text { opzichte van het landbouware- } \\
\text { aal }\end{array}$ & $\begin{array}{l}\text { Waarborg tegen omscha- } \\
\text { keling naar andere land- } \\
\text { bouwtoepassingen met het } \\
\text { oog op het behoud van de } \\
\text { koolstofvoorraad }\end{array}$ & $\begin{array}{l}\text { Bepalen van het schaal niveau van } \\
\text { monitoring (aandeel blijvend gras- } \\
\text { land op gebruikte landbouw grond) } \\
\text { (MVH) }\end{array}$ \\
\hline & $\begin{array}{l}\text { GLMC } 2 \text { Passende bescherming } \\
\text { van wetlands en veengebieden }\end{array}$ & $\begin{array}{l}\text { Bescherming van koolstof- } \\
\text { rijke bodems }\end{array}$ & $\begin{array}{l}\text { Aanwijzing van gebieden waar } \\
\text { maatregel van toepassing is en spe- } \\
\text { cificeren van maatregel voor pas- } \\
\text { sende bescherming } \\
\text { (MVH) }\end{array}$ \\
\hline & $\begin{array}{l}\text { GLMC } 3 \text { Verbod op het verbran- } \\
\text { den van stoppels. }\end{array}$ & $\begin{array}{l}\text { Handhaving van organisch } \\
\text { bodemmateriaal }\end{array}$ & $\begin{array}{l}\text { Geen keuzemogelijkheid } \\
\text { (AB) }\end{array}$ \\
\hline \multirow[t]{2}{*}{ Water } & $\begin{array}{l}\text { GLMC } 4 \text { Aanleg van bufferstroken } \\
\text { langs waterlopen } 1\end{array}$ & $\begin{array}{l}\text { Bescherming van waterlo- } \\
\text { pen tegen vervuiling en af- } \\
\text { vloeiing }\end{array}$ & $\begin{array}{l}\text { Bepalen breedte van bufferstroken } \\
\text { en op welke waterwegen de maat- } \\
\text { regel van toepassing is } \\
\text { (MVH\&AB) }\end{array}$ \\
\hline & $\begin{array}{l}\text { GLMC } 5 \text { Gebruik van het land- } \\
\text { bouwbedrijfsduurzaamheidsinstru- } \\
\text { ment voor nutriënten }\end{array}$ & $\begin{array}{l}\text { Duurzaam beheer van nutri- } \\
\text { enten }\end{array}$ & $\begin{array}{l}\text { Bepalen welk instrument gebruikt } \\
\text { wordt en of er voorwaarden gesteld } \\
\text { worden aan de scores } \\
\text { ((MVH \& AB) }\end{array}$ \\
\hline \multirow[t]{3}{*}{ Bodem } & $\begin{array}{l}\text { GLMC } 6 \text { Bodembewerkingsbe- } \\
\text { heer ter vermindering van het ri- } \\
\text { sico van bodemdegradatie, } \\
\text { waaronder door rekening te hou- } \\
\text { den met hellingen }\end{array}$ & $\begin{array}{l}\text { Minimaal grondbeheer op } \\
\text { basis van de specifieke om- } \\
\text { standigheden ter plaatse } \\
\text { om erosie tegen te gaan }\end{array}$ & $\begin{array}{l}\text { Specificeren van voorwaarden voor } \\
\text { bodembewerking en de gebieden } \\
\text { waarop maatregel van toepassing is. } \\
\text { (AB) }\end{array}$ \\
\hline & $\begin{array}{l}\text { GLMC } 7 \text { Geen kale grond in de } \\
\text { meest gevoelige periode(n) }\end{array}$ & $\begin{array}{l}\text { Bescherming van bodems } \\
\text { in de winter }\end{array}$ & $\begin{array}{l}\text { Bepalen van voorwaarden voor win- } \\
\text { terbedekking (type / duur etc) } \\
\text { (AB) }\end{array}$ \\
\hline & GLMC 8 Gewasrotatie & $\begin{array}{l}\text { Behoud van het bodempo- } \\
\text { tentieel }\end{array}$ & $\begin{array}{l}\text { Bepalen van voorwaarden voor de } \\
\text { gewasrotatie } \\
\text { (AB) }\end{array}$ \\
\hline \multirow[t]{2}{*}{$\begin{array}{l}\text { Biodiversi- } \\
\text { teit en } \\
\text { landschap }\end{array}$} & $\begin{array}{l}\text { GLMC } 9 \text { Minimumaandeel land- } \\
\text { bouwareaal gewijd aan niet-pro- } \\
\text { ductieve elementen of opper- } \\
\text { vlakten. Behoud van landschaps- } \\
\text { elementen. Verbod op snoeien in } \\
\text { de vogelbroedperiode }\end{array}$ & $\begin{array}{l}\text { Instandhouding van niet- } \\
\text { productieve kenmerken en } \\
\text { oppervlakte ter verbetering } \\
\text { van de biodiversiteit op } \\
\text { landbouwbedrijven }\end{array}$ & $\begin{array}{l}\text { Bepalen van het percentage van } \\
\text { het minimum aandeel voor niet-pro- } \\
\text { ductieve elementen en welke typen } \\
\text { van toepassing zijn. } \\
\text { (MVH\&AB) }\end{array}$ \\
\hline & $\begin{array}{l}\text { GLMC } 10 \text { Verbod op het omzet- } \\
\text { ten en ploegen van blijvend gras- } \\
\text { land in Natura } 2000-\text { gebieden }\end{array}$ & $\begin{array}{l}\text { Bescherming van habitats } \\
\text { en soorten }\end{array}$ & $\begin{array}{l}\text { Bepalen areaal waarop verbod van } \\
\text { toepassing is. } \\
(\mathrm{MVH})\end{array}$ \\
\hline
\end{tabular}

Voor biodiversiteit en landschap zijn de laatste twee GLMC's van belang. GLMC 9 moet de biodiversiteit op landbouwbedrijven verbeteren door ervoor te zorgen dat er voldoende niet-productieve elementen en oppervlakten zijn. De GLMC schrijft een minimumaandeel landbouwareaal dat gewijd moet zijn aan niet-productieve elementen of oppervlakten voor. Dit is in feite de maatregel voor Ecological Focus Areas (EFA) van de huidige periode. Verder schrijft de GLMC voor dat landschapselementen behouden moeten blijven en is er een verbod op snoeien in de vogelbroedperiode. Lidstaten kunnen zelf het percentage

2 Tussen haakjes aangegeven op welke sector GLMC van toepassing is, MVH=melkveehouderij, $A B=$ akkerbouw en tuinbouw. 
van het minimum aandeel voor niet-productieve elementen vaststellen welke typen nietproductieve elementen dan van toepassing zijn.

De laatste GLMC 10 is ook een van de vergroeningsmaatregelen van de huidige periode: het is het verbod op het omzetten en ploegen van blijvend grasland in Natura 2000-gebieden, om zo leefgebied en soorten te beschermen. Lidstaten mogen bepalen op welk areaal verbod het verbod van toepassing is.

\subsubsection{De eco-schema's}

Naast de versterkte conditionaliteit kunnen groene doelen binnen de le pijler bediend worden door zogenaamde eco-schema's. Lidstaten zijn verplicht deze eco-schema's in te voeren, maar boeren mogen hier vrijwillig aan deelnemen. Aan de lidstaten is het om te bepalen hoe groot het budget is voor de eco-schema's en hoeveel er dan overblijft voor de 'basis inkomenstoeslag voor duurzaamheid'.

Hoe deze eco-schema eruit gaan zien is nog niet duidelijk en zal per lidstaat verschillen. In het voorstel staat dat: "De lidstaten kunnen besluiten eco-regelingen in te stellen voor landbouwpraktijken zoals een beter beheer van blijvend grasland en landschapselementen, en biologische landbouw. Tot deze regelingen kunnen ook "instapregelingen" behoren die een voorwaarde kunnen zijn voor het aangaan van meer ambitieuze verbintenissen in het kader van de plattelandsontwikkeling".

\section{Doelen}

In de wetsvoorstellen staat dat een van de doelen van het nieuwe GLB het verbeteren van de natuurlijke leefomgeving en verminderen impact klimaatverandering is. Zowel de Europese Commissie als het kabinet wil de ambities en prestaties van het GLB ten aanzien van dit doel verhogen. Het gaat dan om doelen op het gebied van klimaat, natuur, biodiversiteit, landschap, water en bodem. Hiervoor zijn al een heel aantal doelen afgesproken en vastgelegd die als uitgangspunt kunnen worden gebruikt (verder vitgewerkt in Doorn \& Kuneman 2018):

Doelen die bijdragen aan verminderen van en aanpassing aan klimaatverandering: Het regeerakkoord meldt hiervoor de volgende doelen: reductie methaan in 2030 (uit mest en herkauwers): 1 Mton CO2-eq emissiereductie per jaar (ofwel structureel); en aanpassingen aan landgebruik: 1,5 MTon per jaar netto emissiereductie in bv de veenweide en verder kan aangesloten worden bij de doelen klimaattafel landbouw en landgebruik. Voor bodem zijn doelen vast gelegd in het 7th Environmental action program 1386/2013/EU (in 2030 zijn alle gedegradeerde bodems hersteld). Het stimuleren van duurzaam bodemgebruik door tegengaan van bodemerosie en verhogen van bodem organisch materiaal) en meer recent in de Bodemstrategie 23/5/2018, wordt het doel voor 2030 benoemd als alle 
bodems duurzaam beheerd. Als nadere specificering wordt genoemd: voorkomen en opheffen van bodemverdichting en erosie, vasthouden en vastleggen van bodem-organisch stof, voorkomen en stoppen van bodemdaling, stimuleren van bodembiodiversiteit, stimuleren kringlooplandbouw en het zo veel mogelijk sluiten van N, C en P kringlopen.

Voor specifieke doelen t.a.v. waterkwaliteit en -kwantiteit bestaan EU- of nationale beleidsdoelen en kaders. Voor waterkwaliteit gelden de doelen, normen en afspraken binnen de Nitraatrichtlijn ${ }^{3}$ en Kaderrichtlijnwater ${ }^{4}$ : het bereiken van een goede status van waterkwaliteit in rivieren, sloten en meren en voldoen aan Nitraatrichtlijn. Wat betreft de concrete invulling hiervan is het $6^{\circ}$ actieprogramma Nitraatrichtlijn 5 van belang. Specifieke doelen met betrekking tot waterkwantiteit gaan zowel over verdroging, overstroming en verzilting, de opgaven verschillen per grondsoort.

Voor biodiversiteit bestaan een aantal internationale afspraken, welke van status verschillen. Zo is er de Biodiversiteitsconventie, waarin de doelen gevat zijn in 20 zogenaamde Aichi targets ${ }^{6}$, de Europese biodiversiteitsstrategie ${ }^{7}$ en de meer bindende afspraken van de Europese Vogel8- en Habitatrichtlijn?.

Voor de doelen van het GLB zijn onder andere relevant: Aichi Target 7, waarin wordt gesteld dat ten minste $15 \%$ van de aangetaste ecosystemen hersteld moet zijn', in de Nederlandse context kan hier dan gedacht worden aan het stimuleren van natuurinclusieve landbouw, het realiseren van een goede basiskwaliteit op alle landbouwgronden: milieucondities, bodemkwaliteit en groene infrastructuur en bescherming van insecten populaties (inclusief bestuivers). Ook Aichi Target 3 is relevant: deze stelt dat voor biodiversiteitsbehoud en voor een meetbare verbetering in de staat van instandhouding van soorten en habitats die afhangen of invloed ondervinden van de landbouw er een zo groot mogelijke oppervlakte landbouwgrond onder biodiversiteits-gerelateerde maatregelen in het kader van het GLB moet vallen. En Aichi target 8 stelt dat de overschotten aan nutriënten (zoals stikstof) zodanig moeten worden teruggebracht dat ze niet meer bedreigend zijn voor ecosystemen en biodiversiteit. Daarnaast zijn er natuurlijk de doelen van de Vogel- en Habitatrichtlijn van de EU: het bereiken van een gunstige staat van instandhouding voor alle vogels en habitats, zoals het herstel van populaties weide- en akkervogels.

\footnotetext{
3 https://eur-lex.europa.eu/legal-content/NL/TXT/? uri=CELEX\%3A31991L0676

4 https://eur-lex.europa.eu/resource.htmle uri=cellar:5c835afb-2ec6-4577-bdf8756d3d694eeb.0005.02/DOC_1\&format=PDF

5 https://www.rijksoverheid.nl/documenten/rapporten/2017/12/22/zesde-nederlandse-actieprogramma-betreffende-de-nitraatrichtlijn-2018-2021

6 https://www.cbd.int/

7 https://eur-lex.europa.eu/legal-content/NL/TXT/? uri=LEGISSUM\%3Aev0029

8 https://eur-lex.europa.eu/LexUriServ/LexUriServ.do?uri=OJ:L:2010:020:0007:0025:NL:PDF

9 https://eur-lex.europa.eu/LexUriServ/LexUriServ.do?uri=CELEX:31992L0043:NL:HTML
} 
Deze voorgenoemde doelen zijn als uitgangspunt genomen bij het invullen van de keuzemogelijkheden voor lidstaten in het nieuwe GLB. Hierbij is aangenomen dat de doelen voor waterkwaliteit en -kwantiteit overeenkomen met doelen voor klimaat en bodem. Het scoren van maatregelen binnen de versterkte conditionaliteit en eco-scheme's is in deze studie gericht op het bereiken van:

- reductie broeikasgassen uit de landbouw

- koolstofvastlegging in landbouwbodems, dit wordt ook als maat voor bodem- en waterkwaliteit genomen

- bovengrondse- en ondergrondse biodiversiteit

- behoud en bevordering van specifieke soorten.

\section{Invulling van keuzemogelijkheden: overwegingen, aanna- mes en scenario's}

Uit het voorgaande blijkt dat de wetsvoorstellen nog veel ruimte laten voor invulling door de lidstaten. Aangezien nog niet bekend is hoe de Nederlandse invulling er vit gaat zien zal toegelicht worden welke overwegingen er zijn bij de invulling van de versterkte conditionaliteit en de eco-schema's, daarnaast zullen de aannames die gedaan zijn en de gekozen scenario's voor de analyse worden besproken.

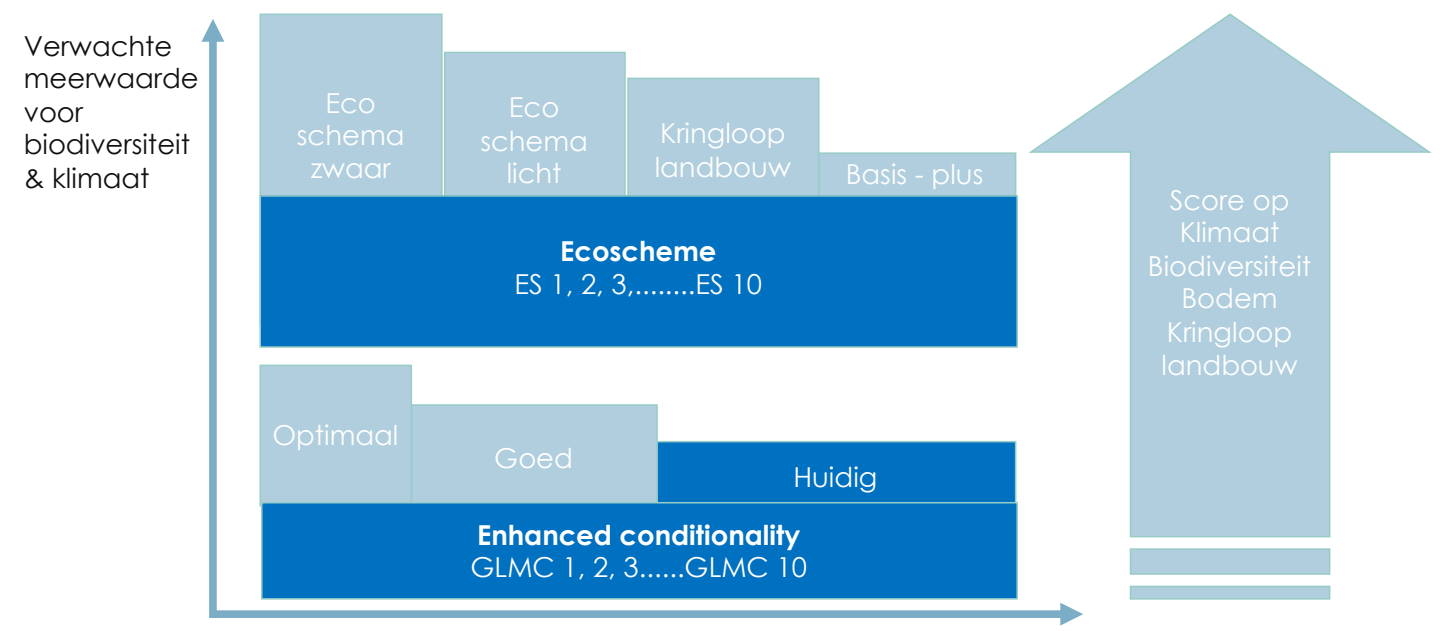

Figuur 2. Schema voor de opties voor de versterkte conditionaliteit en het eco-schema en de te verwachte effecten op klimaat, bodem en biodiversiteit. Pijler II is niet opgenomen in het figuur.

In figuur 2 staat schematisch weergegeven hoe is omgegaan met de keuzemogelijkheden. Het schema van de 'new greening architecture' (figuur 1) is hierbij het uitgangspunt waarin overzichtelijk staat hoe zich de versterkte conditionaliteit, de eco-schema's en 2e pijler zich tot elkaar verhouden.

Belangrijk in de figuur is dat de $\mathrm{x}$-as een indicatie is van het aantal boeren die meedoen en de $y$-as een indicatie is van de te verwachten meenwaarde voor klimaat/biodiversiteit. In het 
schema is alles wat donkerblauw is een vast gegeven, dat wil zeggen onderdeel van de Europese wetsvoorstellen of huidig GLB. De lichter gekleurde vakken geven de mogelijkheden en scenario's aan die in voorliggende studie besproken worden. Op basis van de licht en donkerblauw vlakken wordt viteindelijk een inschatting van de effecten gedaan (aangegeven met de dikke pijl links), de lichtgrijze gedeelten vallen daar dus buiten.

\subsection{Versterkte conditionaliteit}

De door de Europese Commissie voorgeschreven voorwaarden voor een goede landbouw en milieuconditie (GLMC) vormen het uitgangspunt bij de versterkte conditionaliteit. Per GLMC is vervolgens nagegaan welke specificaties er nodig zijn om ze voor Nederland zinvol in te vullen. Hiervoor worden drie niveaus onderscheiden: het huidige niveau is in feite zoals de milieurandvoorwaarden en de vergroeningsmaatregelen in het huidige GLB zijn ingevuld, er is een optimaal niveau waarbij de doelen zoveel mogelijk gehaald worden en een realistisch niveau wat tussen het basis en het optimale niveau in zit qua ambities en doelbereik. De mogelijke specificaties voor de 10 GLMC's staan per niveau in Tabel 2 weergegeven.

Bij de keuze voor het bepalen van de minimale millieu-randvoorwaarden via de versterkte conditionaliteit is het belangrijk de wisselwerking tussen de hoogte van de randvoorwaarden, de vergoedingen die ertegenover staan en het aantal deelnemende boeren goed in de gaten te houden. Met andere woorden, indien de voorwaarden van de versterkte conditionaliteit flink worden aangescherpt, met gelijkblijvende hectarepremies is het mogelijk dat minder boeren gebruik zullen maken van GLB-betalingen en dus minder resultaat geboekt kan worden richting vergroening. Bij het huidige niveau wordt er van uitgegaan dat $90 \%$ van de boeren voldoet en dus in aanmerking komt voor inkomenssteun. Bij het 'goed' niveau is dat al een stuk minder omdat er in de praktijk meer verwacht wordt tav verduurzaming. De definitie van permanent grasland is hier van grote invloed voor de melkveehouderij. Wij stellen voor om het 60-20-20 principe ontwikkeld door Van Eekeren te hanteren op bedrijfsniveau voor minerale gronden: 60\% permanent grasland en $20 \%$ mais en $20 \%$ grasklaver in rotatie. Dit is goed voor bodem, biodiversiteit en ook voor de boer in termen van financieel voordeel. Bij de akkerbouw gaat het vooral om de aanpassing van grondbewerking en het rotatieschema. Vanuit de huidige praktijk zal naar schatting $40 \%$ van de boeren voldoen aan het niveau 'goed' en dus voldoen aan de minimum voorwaarden om GLB-betalingen te ontvangen. Bij het 'optimaal' niveau zijn de opties zodanig gekozen dat de doelen voor 2030 in zicht komen. Het is een aanscherping van de opties onder 'goed'. In de praktijk voldoet slechts $10 \%$ van de boeren hieraan. Bij het optimale niveau zijn de voorwaarden zo hoog dat de verwachting is dat veel boeren niet voldoen aan de minimum voorwaarden en dus geen GLB-betalingen kunnen ontvangen.

Echter, hoe de relatie tussen aangescherpte randvoorwaarden en deelname van boeren precies verloopt, is niet op voorhand te zeggen. Maar de vraag is hoe zoveel mogelijk boeren zo groot mogelijke stappen kunnen zetten om zo dicht bij doelrealisatie te komen? Voor de rest van de studie gaan we uit van het huidige niveau van de randvoorwaarden, dan doet het merendeel van de boeren mee en die kunnen dan op GLB-betalingen rekenen. De 
ambitie voor vergroening zou in dat geval via het eco-schema geregeld moeten worden. Hier moet dan ook het grootste deel van het budget in. Bij het invullen van de eco-schema's is ervan uitgegaan dat het niveau van de versterkte conditionaliteit wordt gehandhaafd op het huidige niveau.

Tabel 2 Mogelijkheden voor voorwaarden voor een goede landbouw en milieu conditie, bij drie verschillende niveaus van een versterkte conditionaliteit

\begin{tabular}{|c|c|c|c|}
\hline \multirow[t]{2}{*}{ Onderdeel } & \multicolumn{3}{|c|}{ Niveaus voor NIdse specificering van GLMC 's } \\
\hline & optimaal & goed & huidig GLB \\
\hline $\begin{array}{l}\text { GLMC } 1 \text { Instandhouding van } \\
\text { blijvend grasland }\end{array}$ & $\begin{array}{l}\text { per bedrijf } 80 \%: 80 \% \\
\text { permanent grasland, } \\
10 \% \text { klaver-gras en } 10 \% \\
\text { mais in rotatie }\end{array}$ & $\begin{array}{l}20-20-60 \text { schema: } 60 \% \\
\text { permanent grasland, } \\
20 \% \text { klaver-gras en } 20 \% \\
\text { mais in rotatie }\end{array}$ & $\begin{array}{l}\text { Ratio voor blijvend gras } \\
\text { wordt op nationaal niveau } \\
\text { gemonitord, 5jr gras }\end{array}$ \\
\hline $\begin{array}{l}\text { GLMC } 2 \text { Passende bescher- } \\
\text { ming van wetlands en veen- } \\
\text { gebieden }\end{array}$ & $\begin{array}{l}\text { Alle Veenweide gron- } \\
\text { den: peilverhoging }\end{array}$ & $\begin{array}{l}\text { Peilverhoging in diepe } \\
\text { veenweide gebieden }\end{array}$ & $\begin{array}{l}\text { Ploeg- en omzet verbod voor } \\
\text { blijvend grasland in veen- } \\
\text { weide }\end{array}$ \\
\hline $\begin{array}{l}\text { GLMC } 3 \text { Verbod op het ver- } \\
\text { branden van stoppels. }\end{array}$ & Totaal verbod & Totaal verbod & Totaal verbod \\
\hline $\begin{array}{l}\text { GLMC } 4 \text { Aanleg van buffer- } \\
\text { stroken langs waterlopen }\end{array}$ & $\begin{array}{l}\text { Alle waterwegen } 5 \mathrm{~m} \\
\text { bufferstrip }\end{array}$ & $1 \mathrm{~m}$ & $50 \mathrm{~cm}$ \\
\hline $\begin{array}{l}\text { GLMC } 5 \text { Gebruik van een } \\
\text { duurzaamheids instrument } \\
\text { voor nutriënten }\end{array}$ & $\begin{array}{l}\text { KLW: score streef- } \\
\text { waarde }\end{array}$ & Score drempelwaarde & $\begin{array}{l}\text { Verplicht gebruik \& inzicht } \\
\text { voor alle boeren (ook AB) }\end{array}$ \\
\hline $\begin{array}{l}\text { GLMC } 6 \text { Bodembewerkings- } \\
\text { beheer ter vermindering van } \\
\text { het risico van bodemdegra- } \\
\text { datie. }\end{array}$ & $\begin{array}{l}\text { Minimale grondbewer- } \\
\text { king }\end{array}$ & $\begin{array}{l}\text { Beperkte gondbewer- } \\
\text { king }\end{array}$ & $\begin{array}{l}\text { Percelen met een helling } \\
\geq 2 \% \text { Ondiep ploegen, per- } \\
\text { ceel met helling > } 18 \% \\
\text { uitstuitend grasland. }\end{array}$ \\
\hline $\begin{array}{l}\text { GLMC } 7 \text { Geen kale grond in } \\
\text { de meest gevoelige peri- } \\
\text { ode(n) }\end{array}$ & $\begin{array}{l}\text { Winterbedekking door } \\
\text { groenbemester }\end{array}$ & $\begin{array}{l}\text { Winterbedekking } \\
\text { groenbemester }\end{array}$ & $\begin{array}{l}\text { Verplicht groenbemester } \\
\text { zaaien op percelen }\end{array}$ \\
\hline GLMC 8 Gewasrotatie & $\begin{array}{l}10-15 \% \text { meerjarige rust- } \\
20 \% \text { bloemrijk max } \\
30 \% \text { rooigewas }\end{array}$ & $\begin{array}{l}10-15 \% \text { meerjarige rust- } \\
\text { gewassen max } 50 \% \\
\text { rooigewassen }\end{array}$ & Minimaal 1:3 \\
\hline $\begin{array}{l}\text { GLMC } 9 \text { Minimumaandeel } \\
\text { landbouwareaal gewijd aan } \\
\text { niet-productieve elementen } \\
\text { of oppervlakten. Behoud van } \\
\text { landschapselementen. }\end{array}$ & $\begin{array}{l}10 \% \text { van bedrijfsareaal } \\
\text { is niet productief ele- } \\
\text { menten, (landschap } \\
\text { en bodem-specifiek) }\end{array}$ & $\begin{array}{l}7 \% \text { van bedrijfsareaal is } \\
\text { niet-productieve ele- } \\
\text { menten (landschap en } \\
\text { bodem-specifiek) }\end{array}$ & $\begin{array}{l}5 \% \text { EFA } \\
\text { Alleen vellen met kennisge- } \\
\text { ving en herplantplicht, }\end{array}$ \\
\hline $\begin{array}{l}\text { GLMC } 10 \text { Verbod op het om- } \\
\text { zetten en ploegen van blij- } \\
\text { vend grasland in Natura } \\
2000 \text {-gebieden }\end{array}$ & $\begin{array}{l}100 \% \text { in Natura2000 \& } \\
\text { HNV gebieden }\end{array}$ & $100 \%$ in Natura2000 & $\begin{array}{l}100 \% \text { in Natura2000 gebie- } \\
\text { den exclusief zand }\end{array}$ \\
\hline
\end{tabular}




\subsection{Eco-schema's}

De wetsvoorstellen laten hier ook nog veel ruimte voor de invulling door lidstaten. In voorliggende studie wordt inzicht gegeven hoe een invulling voor Nederland er vit zou kunnen zien. Aangezien het voor de effectiviteit van beleidsmaatregelen wenselijk is wanneer instrumenten logisch op elkaar aansluiten is de invulling van de eco-schema's zo opgesteld dat deze een logische aanvulling op de versterkte conditionaliteit vormt. Dit is gedaan door de opties voor de eco-schema's te koppelen aan de GLMC's. De opties voor de eco-schema's zijn aangeduid als ES1 - ES 10 en zijn dan ook vergelijkbaar qua doelstelling als GLMC 1 GLMC10. Zie hiervoor figuur 2 en tabel 3. Hierbij is het wel van belang welke specifieke maatregelen, hier opties genoemd, worden gestimuleerd. Er is keuze vit veel gedetailleerde maatregelen uit bijvoorbeeld de Subsidieverordening Natuur- en Landschapsbeheer (SVNL) - beheerjaar 2018 (www.bij12.nl). Hier is gekozen voor generieke opties die een potentiele bijdrage leveren aan de resultaten en gericht zijn op- en rond het perceel. De maatregelen op het perceel zijn relevant voor bodem en klimaat en voor de ondergrondse en bovengrondse biodiversiteit. Rond het perceel maatregelen hebben veel meer relevantie voor de biodiversiteit en de specifieke soorten, maar minder voor klimaat en bodem. Vanuit deze principes zijn we gekomen tot de set van opties voor het eco-schema zoals beschreven in Tabel 3.

In tabel 3 is te zien dat de milieurandvoorwaarde voor behoud van blijvend gras in het ecoschema aangevuld kan worden door het belonen van oud en kruidenrijk gras of wanneer een boer $60 \%$ blijvend gras heeft en $20 \%$ gras-klaver mengsel (optie ES1). De milieurandvoorwaarde voor behoud van wetlands en veengebieden wordt via eco-schema optie 2 (E2) aangevuld met het opzetten van het waterpeil in de betreffende gebieden. De milieurandvoorwaarde voor het handhaven en verbeteren van bodem organische materiaal wordt via eco-schema optie 3 (ES3) aangevuld door het gebruik van ruige mest te belonen. De voorwaarde om bufferstroken langs waterlopen aan te leggen kan via het eco-schema aangevuld worden door bloem- en kruidenrijke randen te stimuleren via eco-schema optie 4 (ES4). De voorwaarde om een duurzaamheidsinstrument voor nutriënten te gebruiken kan de kringloopwijzer zijn, via het eco-schema zouden dan hoge scores op de Kringloopwijzer (KLW) beloond kunnen worden (ES5).

De voorwaarde voor het beschermen van bodem tegen bodemdegradatie, zou via het eco-schema extra gestimuleerd kunnen worden door praktijken als minimale grondbewerking te belonen via eco-schema optie 6 (ES6). Aanvullend op de voorwaarde voor gewasrotatie zouden maatregelen met betrekking tot rust en/of bloemrijke gewassen beloond kunnen worden (ES8)

De voorwaarde om een bepaald percentage van het bedrijfsareaal te bestemmen voor niet productieve elementen zou via het eco-schema aangevuld kunnen worden door het belonen van de aanleg van landschapselementen en het inzaaien van bloem- en kruidenrijke randen (ES9). Tenslotte de voorwaarde voor het verbod op het ploegen en omzetten 
van blijvend gras in Natura2000 gebieden zou via het eco-schema aangevuld kunnen worden om de boeren in die gebieden extra te ondersteunen om minder kunstmest en bestrijdingsmiddelen te gebruiken (ES10).

Tabel 3. Scenario's voor invulling van het eco-schema, bedragen van de toeslagen en geschat areaal gebaseerd op Terluin et al 2018.

\begin{tabular}{|c|c|c|c|c|}
\hline \multirow[t]{2}{*}{$\begin{array}{l}\text { Opties voor het eco-scheme } \\
\text { (ES) }\end{array}$} & \multicolumn{4}{|c|}{ Scenarios voor Nldse invulling van eco-schema } \\
\hline & basis plus & Ecoscheme - licht & Ecoscheme - zwaar & Kringlooplandbouw \\
\hline $\begin{array}{l}\text { Inkomenstoeslag } \\
\text { Eco-scheme toeslag } \\
\text { Totale 1e pijler toeslag } \\
\text { Aantal ha }\left({ }^{*} 1000\right) \text { onder } \\
\text { eco-scheme }{ }^{10} \\
\% \text { areaal onder eco-scheme }\end{array}$ & $\begin{array}{l}184 € / \text { ha } \\
205 € / \text { ha } \\
389 € / \text { ha } \\
1.606 \text { ha } \times 1000 \\
90 \%\end{array}$ & $\begin{array}{l}92 € / \text { ha } \\
425 € / \text { ha } \\
517 € / \text { ha } \\
1.160 \text { ha } \times 1000 \\
65 \%\end{array}$ & $\begin{array}{l}62 € / \text { ha } \\
1.650 € / \text { ha } \\
1.711 € / \text { ha } \\
268 \text { ha } \times 1000 \\
15 \%\end{array}$ & $\begin{array}{l}77 € / \text { ha } \\
580 € / \text { ha } \\
657 € / \text { ha } \\
714 \text { ha } \times 1000 \\
40 \%\end{array}$ \\
\hline $\begin{array}{l}\text { ES1: Grasland: kruidenrijk of } \\
\text { langer blijvend } \\
\text { ES2: handhaven hoge gwt } \\
\text { ES3: gebruik ruige stalmest } \\
\text { ipv andere bemesting } \\
\text { ES4 bufferstroken bloem- } \\
\text { rijk/kruidenrijk } \\
\text { ES5: hogere scores op KLW } \\
\text { ES6: beperkte grond bewer- } \\
\text { king op al het bouwland; } \\
\text { conservation agriculture } \\
\text { ES7 : groenbemesters } \\
\text { ES8: } 10 \text {-15\% meerjarige rust- } \\
\text { gewassen, } 20 \% \text { bloemrijke } \\
\text { gewassen max } 30 \% \text { rooige- } \\
\text { wassen } \\
\text { ES9 bloem- en kruidenrijk } \\
\text { aanleg nieuwe landschaps- } \\
\text { elementen } \\
\text { ES10 bio premie voor bio- } \\
\text { boeren binnen EHS }\end{array}$ & $\begin{array}{l}\text { Biodiversiteit: } \\
\text { ES4 bloem/krui- } \\
\text { denrijke buffer- } \\
\text { stroken } \\
\text { ES9 boem/krui- } \\
\text { denrijke randen }\end{array}$ & $\begin{array}{l}\text { Biodiversiteit: } \\
\text { ES1 60-20-20 } \\
\text { ES3: gebruik ruige } \\
\text { stalmest ipv an- } \\
\text { dere bemesting } \\
\text { ES4 bloem/krui- } \\
\text { denrijke bufferstro- } \\
\text { ken } \\
\text { ES9 boem/kruiden- } \\
\text { rijke randen }\end{array}$ & $\begin{array}{l}\text { Klimaat: } \\
\text { ES1 oud gras > } 10 \text { jr } \\
\text { ES2 hoge GWT in alle } \\
\text { veenweide } \\
\text { ES5 hoge scores op de } \\
\text { KLW } \\
\text { ES6 minimale grondbe- } \\
\text { werking } \\
\text { ES8: } 10 \text {-15\% meerjarige } \\
\text { ustgewassen, } 20 \% \\
\text { bloemrijke gewassen } \\
\text { max } 30 \% \text { rooigewassen } \\
\text { Biodiversiteit } \\
\text { ES1 } 10 \% \text { kruidenrijk } \\
\text { ES2 aanleg plasdras } \\
\text { ES3: gebruik ruige stal- } \\
\text { mest ipv andere bemes- } \\
\text { ting } \\
\text { ES4 bloem/kruidenrijke } \\
\text { pufferstroken } \\
\text { ES9 boem/kruidenrijke } \\
\text { tanden }\end{array}$ & $\begin{array}{l}\text { Biodiversiteit } \\
\text { ES1 60-20-20 } \\
\text { ES3: gebruik ruige } \\
\text { stalmest ipv an- } \\
\text { dere bemesting } \\
\text { ES4 bloem/krui- } \\
\text { denrijke bufferstro- } \\
\text { ken } \\
\text { ES9 boem/kruiden- } \\
\text { rijke randen }\end{array}$ \\
\hline
\end{tabular}

De bovenbeschreven opties voor het eco-schema kunnen lichter dan wel zwaarder ingezet worden, afhankelijk van het beschikbare budget voor het eco-schema. Hier wordt aangesloten bij drie scenario's die door de WUR beschreven zijn (Terluin et al 2018). Van die studie is het Basis - plus, het Eco-schema - licht, Eco-schema - zwaar en Kringlooplandbouw scenario gebruikt. De WUR-studie geeft per scenario de te verwachten toeslagen voor het eco-

10 Aandeel van alle boeren / of betalingsgerechtigde boeren (met toeslagrechten) 
schema, het aandeel boeren dat naar verwachting deel zal nemen, en het areaal met een eco-schema toeslag zie tabel 3 , tweede regel.

De 3 scenario's zijn gevuld met de bovenbeschreven opties voor het eco-schema, zodanig dat deze redelijkerwijs passen binnen de verwachte toeslag. Dus op basis van de verdeling in geld is de ambitie van het eco-schema ingevuld. Dat is gedaan voor nadruk op klimaat en biodiversiteit, voor melkveehouderij en akkerbouw.

\section{Methode voor het bepalen van de bijdrage aan doelen}

Het inschatten van de effecten op biodiversiteit, klimaat en bodem van de mogelijk verschillende invullingen van het eco-schema is kwalitatief gedaan op basis van de beschikbare kennis en expert judgement. De scenario's zijn beoordeeld aan de hand van een expert judgement (score). Hiertoe zijn verschillende onderzoekers van de WUR en het Louis Bolk Instituut geraadpleegd. Verder zijn er gesprekken gevoerd met verschillende mensen van diverse organisaties (Vewin, WNF, Regiebureau PoP3, Transitiecoalitie Voedsel) over doelen, opties en methodieken voor kwantificering. De maatregelen per scenario voor het eco-schema zijn gescoord op te verwachte effecten per ES. Vervolgens is een methodiek gehanteerd om de bijdrage van de eco-schema opties aan het doel in 2030 in te schatten. Hiervoor hebben de maatregelen een score van 0-10 gekregen, waarbij een 10 volledige bijdrage aan het doel levert en bij 0 geen enkele.

De puntentoekenning verschillen voor klimaat, bodem en biodiversiteit. De aannames zijn als volgt:

Klimaat: een weging tussen reductie van broeikasgassen en koolstofvastlegging in de bodem. Wanneer met de optie potentieel methaan of lachgas wordt verminderd (grootste bron landbouw) tot aan doel 2030 is de score 10. Als de vastlegging in de bodem potentieel tot 1 Mton leidt in 2030 is de score 10.

Bodem: bodemkwaliteit is hier gelijk genomen aan de score van de koolstofvastlegging, aangezien er vanuit gegaan wordt dat als de bodem koolstof vastlegt het organische stofgehalte toeneemt en daarmee de bodemkwaliteit. Op deze manier wordt de bodem duurzaam beheerd. Als de vastlegging potentieel tot 1 Mton leidt in 2030 is de score 10.

Biodiversiteit: de doelen zijn hier minder concreet en daarom hebben we een expert judgement gebaseerd op drie onderdelen die elk 10 punten kunnen scoren: de bovengrondse biodiversiteit zijnde de bloemrijkheid en de insecten als basis voor het voedselweb. De ondergrondse biodiversiteit die gelijk oploopt met de koolstofvastlegging omdat meer organisch stof bijdraagt aan bodemleven en bodemkwaliteit en tenslotte verbeteren van de kwaliteit van habitats voor specifieke soorten.

Vervolgens is bepaald op hoeveel hectare de optie potentieel kan worden vitgevoerd, separaat voor de melkveehouderij (max 120000 ha) en akker-en tuinbouw (max 600.000 ha). 
Tot slot is de deelname per scenario van de boeren per optie direct gebruikt als inschatting op hoeveel hectare de optie wordt toegepast. Twee voorbeelden van de toekenning van de scores:

Permanent grasland op 60\% van het bedrijfsareaal (ES1, lichte scenario), wanneer dat langer dan 10-20 jaar niet geploegd is wordt veel koolstof vastgelegd. De score voor bodemkwaliteit en klimaat is dan een 8 om te komen tot het doel van koolstofvastlegging in 2030. In principe kan het toegepast worden op $100 \%$ van het grasland. Als $65 \%$ van hun boeren dit op $60 \%$ van hun land doen, dan krijgt deze optie de score:

$8 \times 100 \% \times 65 \% \times 60 \%=3,12$, een relatief hoge score om het doel te bereiken (ten opzichte van andere maatregelen).

Plas-dras systeem (ES2, zware scenario): levert hoge bijdrage aan doelstelling voor specifieke soorten (weidevogels), waardoor de score een 8 is. Het betreft $10 \%$ van de hectare grasland waar dit relevant kan zijn. Als vervolgens $15 \%$ van de boeren een systeem aanleggen, dan is de score: $8 \times 10 \% \times 15 \%=0.12$, terwijl de maximale score 10 kan zijn. Dit voorbeeld maakt duidelijk dat hoewel plas-dras systemen in kansrijk gebieden een effectieve maatregel is, de score in deze berekening laag is vanwege het beperkte areaal. Een lage score geeft dus niet per definitie aan dat een maatregel niet-effectief is. Lokaal kan dit een grote bijdrage leveren aan behoud of bevorderen biodiversiteit en specifieke soorten.

De beoordeling van de opties voor de verschillende scenario's voor de eco-schema's in relatie tot klimaat, biodiversiteit en bodem is gebaseerd op de selectie van opties voor de verschillende scenario's uit Tabel 3.

Bij de presentatie van de resultaten wordt steeds aangegeven: hoe ver zijn wij met deze scenario's op weg naar realisatie van het doel in 2030. De doelen beschreven in hoofdstuk 3 zijn hierin leidend. De resultaten worden weliswaar met een score aangegeven maar die dient niet in absolute termen te worden gebruikt. Het gaat om de onderlinge vergelijking van de scenario's en de bijdrage aan resultaten. Aan het einde van dit hoofdstuk worden de resultaten in breder perspectief besproken.

$E r$ is op twee manieren naar de scenario's worden gekeken. In eerste plaats zijn alle voor het scenario van toepassing zijnde opties geselecteerd, gescoord en opgeteld. De bijkomende kosten, gebaseerd op huidige vergoedingen zoals gehanteerd in de catalogus Groen-blauwe diensten, het agrarisch natuurbeheer en de vergroeningsmaatregelen, zijn ook opgeteld.

Bij de tweede beoordeling is een selectie gemaakt van de meest effectieve opties per scenario zodat zo dicht mogelijk bij het beschikbare budget gebleven kan worden. Het beschikbare budget is berekend door WUR-LEl (Terluin et al. 2018). De beoordeling is opnieuw voor melkveehouderij ( 1.2 miljoen hectare grasland) en akker- en tuinbouw (0.6 miljoen hectare akkerbouw en tuinbouw) apart gedaan. Er is ervan uitgegaan dat $90 \%$ van de boeren 
meedoen in GLB ('Huidig' scenario voor de enhanced conditionality, zie Hfdst 4). De opties zijn ingeschat op relevantie voor de hectares. Bijvoorbeeld het veenweidegebied is $30 \%$ van het totaal grasland areaal en maatregelen voor veenweide zoals peilbeheer en drainage zijn dan ook alleen voor dat aandeel grasland geldig.

\section{Score van de eco-schema scenario's op effecten voor kli- maat, biodiversiteit en bodem}

\subsection{Potentieel haalbare resultaten}

Figuur 3 geeft de scores van de verschillende scenario's voor het eco-schema weer voor de melkveehouderij (A) en akkerbouw (C). De potentiele deelname, de beschikbare en relevante hectares en de scores voor de drie thema's bepalen tezamen de vitkomst in Figuur 3. Bij zowel de melkveehouderij als ook de akkerbouw scoort het eco-schema - licht het beste en de opties dragen rond de 50\% aan de realisatie van de doelen in 2030. De kosten hiervoor liggen rond de $4000 € /$ ha. Het Kringlooplandbouw scenario scoort vergelijkbaar als het zware scenario, maar met aanzienlijk minder kosten. De kosten voor het zware eco-schema liggen tweemaal zo hoog als het lichte scenario, terwijl de realisatie naar doelen lager is (veel minder hectares). Voor klimaat en bodem is de score hoger dan voor biodiversiteit. Dit komt omdat er gekozen is voor zoveel mogelijk maatregelen op de percelen. Voor de stimulans van biodiversiteit (specifieke soorten) zijn specifieke maatregelen als akkerranden, plasdras, landschapselementen, etc. effectiever. De perceel maatregelen dragen wel bij aan het herstel van het voedsel web (bodemleven, insecten, etc.).

\subsection{Scores binnen beschikbare budget}

Indien de scenario's binnen het beschikbare budget (zie Tabel 3) moeten passen, kunnen niet alle opties in het eco-schema worden meegenomen en moet er gekozen worden. Op basis van de kosten per optie (zie Bijlage) en het beschikbare budget zijn met behulp van de scores de beste opties geselecteerd die passend binnen het beschikbare GLB-budget uitgevoerd zouden kunnen worden. Het resultaat is in figuur 3 voor de melkveehouderij (B) en akkerbouw (D) gegeven. Goed te zien is dat de kosten nu veel lager liggen, maar dat het doelbereik ook verder weg is. De twee scenario's eco-scheme - licht en kringlooplandbouw scoren nu vergelijkbaar: rond de $20 \%$ richting doelen 2030. De kosten voor de kringlooplandbouw maatregelen zijn vergelijkbaar voor de melkveehouderij, maar voor de kringlooplandbouw lager dan eco-schema-licht voor de akkerbouw. Opnieuw blijft de biodiversiteitscore achter bij klimaat en bodem. De beschikbare hectare vergoeding is vele malen lager dan die gesommeerd bij het maximaal haalbare resultaat (Figuur $3 \mathrm{~A}$ en C). 


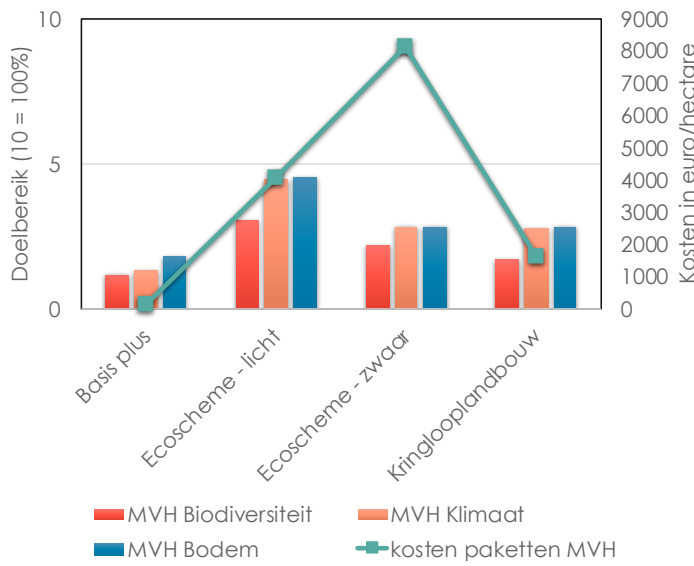

A

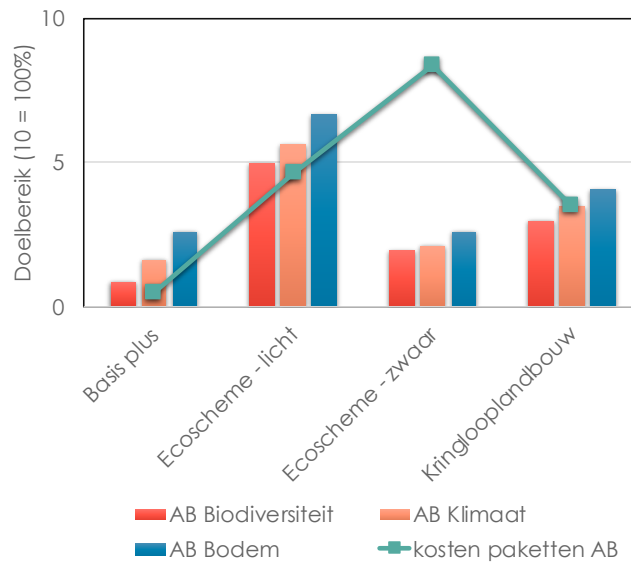

C

Figuur 3. Resultaten voor de scenario's als bijdrage aan realisatie doelstelling 2030 voor biodiversiteit, klimaat en bodem voor melkveehouderij en akkerbouw. A: melkveehouderij maximaal haalbaar en B: binnen de beschikbare budgetten. C: akkerbouw maximaal haalbaar en D: binnen de beschikbare budgetten. De kolommen geven de score van de verschillende scenario's weer op biodiversiteit (blauw), klimaat (oranje) en bodem (grijs). De lijnen geven de gesommeerde kosten weer.

\subsection{Het bredere perspectief}

Figuur 4 geeft de vergelijking van de verschillende scenario's weer in onderlinge vergelijking voor de melkveehouderij en akkerbouw. De stappen die met het nieuwe GLB gemaakt kunnen worden zullen binnen de akkerbouw meer resultaat sorteren volgens deze analyse dan in de melkveehouderij, ondanks dat de meeste opties voor de melkveehouderij gelden.

Kringlooplandbouw is een goede inzet, maar eco-schema - licht scoort net iets beter. 


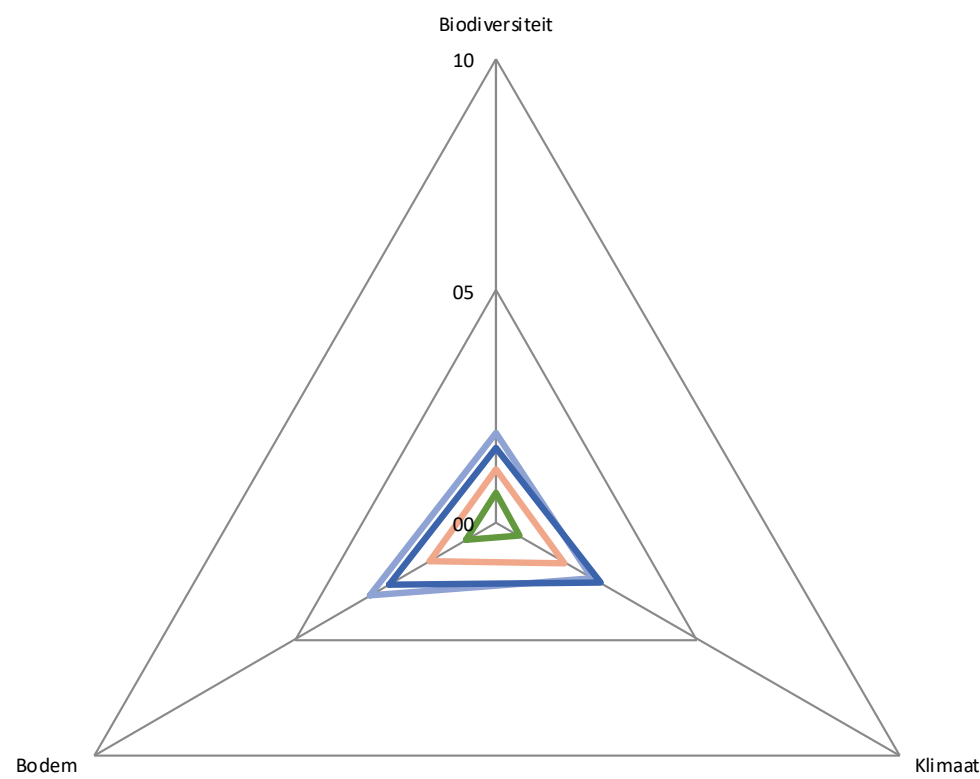

Basis plus

Ecoscheme - licht

Kringlooplandbouw

Ecoscheme - zwaar

A. Melkveehouderij

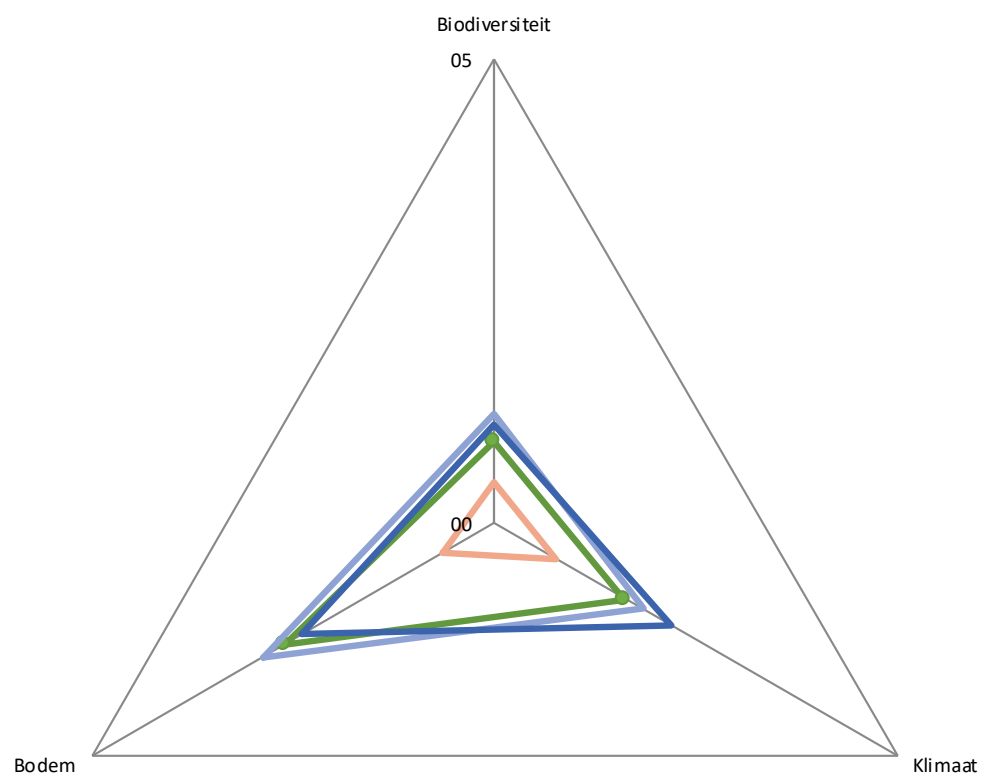

-Basis plus

Ecoscheme - licht

Kringlooplandbouw

Ecoscheme - zwaar

\section{B. Akkerbouw}

Figuur 4 Vergelijking van de scenario's passend binnen het budget voor de melkveehouderij (A) en akkerbouw (B).

Vanuit deze analyse kunnen we ook aangeven wat de meest kosteneffectieve opties zijn binnen de voorstellen van GLB. Hier baseren we ons op de scores door experts van de opties. Tabel 4 geeft een overzicht van de beste opties voor de melkveehouderij (MVH) en akkerbouw (AB) voor maatregelen op en rond het perceel. Dit laatste onderscheid is belangrijk om te maken omdat op het perceel de maatregelen voornamelijk van belang zijn voor de bodem en klimaat en de basis voor het voedselweb (biodiversiteit), terwijl de maatregelen rond het perceel veel bijdragen aan biodiversiteit, maar weinig aan klimaat en bodem 
(door de beperkte oppervlakten). Op het perceel zijn de bodemmaatregelen vooral van belang voor akkerbouw en grasland voor melkveehouderij tbv klimaat.

Opties die er duidelijk uitspringen zijn beperking van grondbewerking in de akkerbouw, de $5 \%$ randzones, gewasrotaties, de score in de Kringloopwijzer en het 60-20-20 principe op bedrijfsniveau (Van Eekeren et al. 2016) voor minerale gronden. Het laatste gaat uit van $60 \%$ permanent grasland en $20 \%$ mais en $20 \%$ grasklaver in rotatie voor het bedrijf en heeft beperkte kosten en volgens Van Eekeren zelfs een netto positief financieel resultaat. Dit is goed voor bodem, biodiversiteit en ook voor de boer in termen van financieel voordeel.

De analyse is gedaan voor biodiversiteit, bodem en klimaat aangezien dit de thema's zijn die ook de andere thema's afdekken, zoals waterkwaliteit en kwantiteit (bodem, nutriënten) en ook stikstofdruk op natuur (kringloop sluiten).

Tabel 4 Effectiviteit van maatregelen

Klimaat $\begin{aligned} & \text { Biodiver- } \\ & \text { siteit }\end{aligned}$ Bodem integraal

\section{Op het perceel}

Permanent grasland (60-20-20; $\mathrm{MVH})$

Peilbeheer en drainage

Bemesting, kringlopen, type (vaste) mest en compost: via score Kringloopwijzer ( $\mathrm{AB}$ en $\mathrm{MVH}$ )

Rust/maaigewas/groenbemesters bouwplan (graan en eiwitgewassen; $A B$ )

Niet kerende grondbewerking, minimale grondbewerking ( $A B$ en $\mathrm{MVH}$, mais)

\section{Rond het perceel}

Bloemrijke akkerranden, bufferstroken met dubbelfunctie: bufferstroken, plaagbestrijding, natuur ( $A B$ en $M V H$ )

Landschapselementen

$\begin{array}{cccc}++ & + & ++ & ++ \\ ++ & + & 0 & + \\ + & + & ++ & + \\ ++ & + & ++ & + \\ + & + & ++ & + \\ 0 & ++ & 0 & + \\ + & ++ & 0 & +\end{array}$

\section{Conclusies en aanbevelingen}

Er is veel ruimte voor keuzes binnen de wetsvoorstellen voor het nieuwe GLB. Lidstaten moeten hun eigen ambitie kiezen, budgetten verdelen over de verschillende instrumenten en maatregelen en voorwaarden bepalen. De analyse die hier gedaan is geeft vanuit doelrealisatie handvatten voor die keuzes. De resultaten dienen ook als zodanig gebruikt te worden omdat de vele aannames en onzekerheden een kwantitatieve analyse nog niet mogelijk maken.

De viteindelijke bijdrage van het GLB aan bodem-, klimaat en biodiversiteitsdoelen is het resultaat van een samenspel tussen voorwaarden en maatregelen, de hoogte van de hectare toeslag en aantal deelnemende boeren. De resultaten van deze studie laten zien wat mogelijkheden zijn voor de verschillende keuzes ten aanzien van toeslagen en maatregelen 
indien er vanuit doelen wordt geredeneerd. Duidelijk komt naar voren dat keuzes bepalend zijn voor de kosten en resultaten en dus de kosteneffectiviteit van opties.

Om toe te werken naar een effectieve invulling van het GLB voor Nederland is het dan ook van belang om eerst te focussen op de vraag wat de doelen en opgaven zijn waar het GLB op zou moeten worden gericht en vervolgens hoe deze het beste via welk instrument binnen het GLB kunnen worden bediend. Om een goede afweging te maken hoe de versterkte conditionaliteit en de eco-schema's moeten worden ingezet is het dus cruciaal eerst de opgaven in het landelijk gebied ten aanzien van natuur, milieu, water, klimaat, biodiversiteit en landschap goed te identificeren, bijvoorbeeld door middel van een SWOT-analyse. Via de versterkte conditionaliteit kunnen de minimale milieurandvoorwaarden voor GLB-betalingen worden bepaald. Het verdient een zorgvuldige afweging welke voorwaarden hiervoor gelden en welke prestaties betaald worden via de eco-schema's. Voor sommige opgaven is het van belang dat zo veel mogelijk boeren mee doen (bv klimaat en bodem opgaven): dan valt er wat voor te zeggen de randvoonwaarden voor de versterkte conditionaliteit niet al te hoog te stellen, omdat er een kans is dat de te verwachte deelname afneemt.

De eco-schema's dienen om prestaties van boeren voor klimaat, bodem en biodiversiteit die verder gaan dan de versterkte conditionaliteit te belonen. In onze analyse komt het scenario eco-schema - licht en het kringloopscenario het beste uit de bus, omdat zoveel mogelijk boeren (hectares) worden gestimuleerd om deel te nemen en omdat daarmee de stappen richting realisatie doelen 2030 naar verwachting het grootst zullen zijn (Figuur 3). Dit geldt vooral voor klimaat en bodem. Biodiversiteit blijft iets achter, maar door via de versterkte conditionaliteit te zorgen voor een goede basiskwaliteit kunnen via pijler II specifieke maatregelen -voor biodiversiteit genomen worden. Van belang is daarbij om de maatregelen binnen de melkveehouderij en akkerbouw te richten op het perceelsniveau voor de doelen klimaat en bodem (inclusief water) en basis voor biodiversiteit, en voor de maatregelen rond het perceel voor biodiversiteit en specifieke soorten. Er kunnen grote stappen gemaakt worden, maar dat is sterk afhankelijk van de keuze van maatregelen. Vanuit de doelen zijn maatregelen te selecteren die integraal tegen redelijke kosten goede resultaten boeken. De analysemethode die hier is ontwikkeld en toegepast biedt goede mogelijkheden om die selectie te doen en de effectiviteit te bepalen.

Met de huidige kosten cq inschatting van inkomstenderving zal het in de praktijk moeilijk worden om grote stappen te maken. In de melkveehouderij is zo'n 4000 en in de akkerbouw $2000 € /$ ha nodig om richting de 50\% doelrealisatie 2030 te kunnen komen. De beschikbare budgetten in de verschillende scenario's zijn hier maar een fractie van.

Passend binnen het budget is het mogelijk om bij de juiste keuze naar zo'n $20 \%$ doelrealisatie te gaan. Dit is meer dan een verdubbeling tov het huidige GLB en daarmee worden stappen gezet richting meer vergroeningsresultaat. Hierbij zouden de eisen voor de versterkte conditionaliteit zodanig kunnen worden gesteld dat veel boeren gebruik blijven maken van GLB-betalingen en de eco-schema's ingezet volgens de scenario's eco-scheme - 
licht of kringlooplandbouw. Het eco-schema kan zo veel mogelijk worden ingezet op hectare winst (op het perceel), en om ruimte te geven voor algemene biodiversiteit langs de percelen. Pijler II wordt dan voornamelijk gericht op maatregelen in gebieden waar de biodiversiteitspotentieel het grootst is, en waar specifieke soorten zoals weidevogels moeten worden beschermd. Het gaat dan om maatregelen als bijvoorbeeld plasdras.

Aangezien de inschatting is dat met het beschikbare budget ongeveer $20 \%$ doelrealisatie te behalen valt, kan ook geconcludeerd worden dat het GLB een belangrijk beleidsspoor is om bij te dragen aan klimaat-, bodem en biodiversiteitsdoelen, maar dat het GLB alleen niet voldoende is om deze doelen ook geheel te realiseren. Daarvoor zal ook vanuit andere beleidssporen en uit de markt inspanningen moeten worden geleverd.

\section{Literatuur}

Doorn A van Kuneman G 2018 Doelenkader GLB2020. Een verkenning voor vitwerking voor Nederland. WENR rapportXX

EC (Europese Commissie) (2017). De toekomst van voeding en landbouw. Mededeling van de Commissie aan het Europees Parlement, de Raad, het Europees Economisch en Sociaal Comité en het Comité van de Regio's, COM(2017) 713 def. Brussel, 29.11.2017.

EC (2018a). Regulation of the European Parliament and of the Council establishing rules on support for strategic plans to be drawn up by Member States under the Common agricultural policy (CAP Strategic Plans) and financed by the European Agricultural Guarantee Fund (EAGF) and by the European Agricultural Fund for Rural Development (EAFRD) and repealing Regulation (EU) No 1305/2013 of the European Parliament and of the Council and Regulation (EU) No 1307/2013 of the European Parliament and of the Council. $\operatorname{COM}(2018) 392$ final. Brussel, 1.6.2018.

EC (2018b). EU-begroting: het GLB na 2020. Brussel, factsheet, via website: https://ec.europa.eu/commission/sites/beta-political/files/budget-may2018-modernisingcap_nl_0.pdf.Terluin, Ida, Petra Berkhout, Jakob Jager, Harold van der Meulen. 2018 Verkenning gevolgen GLB-voorstellen voor landbouwinkomens in Nederland. Wageningen, Wageningen Economic Research, Rapport

Van Eekeren, N. 2016a. Optimaal landgebruik voor bodemkwaliteit: $60 \%$ blijvend grasland en $20 \%$ grasklaver in rotatie met $20 \%$ snijmaiis. V-focus. December, p. 34-35.

Van Eekeren, N., S. van de Goor, J. de Wit, A. Evers, M. de Haan. 2016b. Inkomen 7.000 euro hoger bij betere bodemkwaliteit. V-focus. December, p. 36-37. 


\section{Bijlage 1: Beschrijving van de mogelijke opties}

Tabel x. Beschrijving van de verschillende opties voor de GLMC en ES met daarbij een korte omschrijving, de kosten en de toepassing in de verschillende scenario's.

\begin{tabular}{|c|c|c|c|c|c|}
\hline Thema & CLMC & ES & Optie & Beschrijving & $\begin{array}{l}\text { vergoeding obv } \\
\text { CGBD / ANLb / } \\
\text { vergroenings- } \\
\text { premie } €\end{array}$ \\
\hline \multirow[t]{11}{*}{ Klimaat } & GLMC1 & ES1 & permanent gras nu & $\begin{array}{l}\text { Gras dat voor ten minste vijf jaar niet in de } \\
\text { vruchtwisseling is meegenomen. Ratio voor blijvend } \\
\text { gras wordt op nationaal niveau gemonitord, 5jr gras }\end{array}$ & 135 \\
\hline & GLMCl & ES1 & permanent gras $60-20-20$ & $\begin{array}{l}20-20-60 \text { schema: } 60 \% \text { permanent grasland, } 20 \% \text { kla- } \\
\text { ver-gras en } 20 \% \text { mais in rotatie op minerale gronden } \\
\text { (Van Eekeren et al. } 2016 \text { ) }\end{array}$ & 200 \\
\hline & GLMC1 & ES1 & permanent gras $80-10-10$ & $\begin{array}{l}10-10-80 \text { schema: } 80 \% \text { permanent grasland, } 10 \% \text { kla- } \\
\text { ver-gras en } 10 \% \text { mais in rotatie op minerale gronden. } \\
\text { Variant van } 20-20-60 \text { (zie boven) }\end{array}$ & 325 \\
\hline & GLMC 1 & ES1 & $\begin{array}{l}\text { Uitstel maaien zonder bemes- } \\
\text { ten }\end{array}$ & $\begin{array}{l}\text { Uitstel maaien tot } 15 \text { juni, geen bemesting tot } 15 \text { juni, } \\
\text { alleen voor vogelgebieden }\end{array}$ & 650 \\
\hline & GLMC1 & ES1 & kruidenrijk gras & $\begin{array}{l}\text { minimaal } 15 \text { soorten in grasland aanwezig met pas- } \\
\text { send beheer om de kwaliteit te behouden }\end{array}$ & 1200 \\
\hline & GLMC2 & ES2 & Plas-dras & $\begin{array}{l}\text { Aanleg van plas-dras door peilbeheer of door aan- } \\
\text { leg. Beheer conform ANB }\end{array}$ & 2000 \\
\hline & GLMC2 & ES2 & Plas-dras & $\begin{array}{l}\text { Aanleg van plas-dras door peilbeheer of door aan- } \\
\text { leg. Beheer conform ANB }\end{array}$ & 2000 \\
\hline & GLMC2 & ES2 & onderwater drainage & $\begin{array}{l}\text { Voorkomen bodemdaling door aanleg drainage sys- } \\
\text { teem }\end{array}$ & 2000 \\
\hline & GLMC2 & ES2 & $\begin{array}{l}\text { hoge GWT in diepe veen- } \\
\text { weide }\end{array}$ & Peilbeheer tot $60 \mathrm{~cm}$ onder toplaag & 500 \\
\hline & GLMC2 & ES2 & hoge GWT in alle veenweide & Peilbeheer tot $60 \mathrm{~cm}$ onder toplaag & 500 \\
\hline & GLMC3 & ES3 & Ruige stalmest ipv drijfmest & $\begin{array}{l}\text { Vergt aanpassing stalsystemen om gescheiden } \\
\text { mestopvang toetepassen. Kwaliteit van ruige mest } \\
\text { verbeteren door fermenteren met bv stro. Vanwege } \\
\text { stalaanpassing is inschatting relevantie } 30 \% \text { boeren }\end{array}$ & 200 \\
\hline \multirow[t]{4}{*}{ Water } & GLMC4 & ES4 & $\begin{array}{l}\text { bloem/kruidenrijke bufferstro- } \\
\text { ken (met ES9) }\end{array}$ & $\begin{array}{l}\text { Minimaal } 5 \% \text { van het areaal aan randen met functie } \\
\text { bufferstroken }\end{array}$ & $650(300-1000)$ \\
\hline & GLMC5 & ES5 & scores op de KLW: informatie & $\begin{array}{l}\text { situatie nu: KLW verplicht in MVH. Ook akkerbouw } \\
\text { verplichten KLW toe te passen }\end{array}$ & 0 \\
\hline & GLMC5 & ES5 & $\begin{array}{l}\text { goede scores op de KLW: bo- } \\
\text { vengemiddeld bedrijf }\end{array}$ & $\begin{array}{l}\text { ledereen voldoet aan score van gemiddelde situatie } \\
2018(\mathrm{MVH} \text { en } \mathrm{AB})\end{array}$ & 500 \\
\hline & GLMC5 & ES5 & $\begin{array}{l}\text { goede scores op de KLW: } \\
\text { Koplopers score }\end{array}$ & $\begin{array}{l}\text { Voldoen aan de top } 10 \% \text { prestaties in } 2018 \text { (MVH en } \\
A B \text { ) }\end{array}$ & 1000 \\
\hline \multirow[t]{4}{*}{ Bodem } & GLMC6 & ES6 & beperkte grondbewerking & $\begin{array}{l}\text { MVH: toepassing voor niet-permanent grasland, } \\
\text { aanname } 20 \%, A B \text { volledige toepassing }\end{array}$ & 200 \\
\hline & GLMC6 & ES6 & $\begin{array}{l}\text { geen grondbewerking met } \\
\text { rustgewas }\end{array}$ & $\begin{array}{l}\text { MVH: toepassing voor niet-permanent grasland, } \\
\text { aanname } 20 \% \text {, AB volledige toepassing }\end{array}$ & 500 \\
\hline & GLMC8 & ES8 & Rotatie 1:3 & $\begin{array}{l}\text { Bouwplan: } 10-15 \% \text { meerjarige rustgewassen, max } \\
30 \% \text { rooigewassen }\end{array}$ & 500 \\
\hline & GLMC8 & ES8 & Rotatie 1:4 & $\begin{array}{l}\text { Bouwplan: } 10-15 \% \text { meerjarige rustgewassen, } 20 \% \\
\text { bloemrijke gewassen max 30\% rooigewassen }\end{array}$ & 600 \\
\hline
\end{tabular}




\begin{tabular}{|c|c|c|c|c|c|}
\hline \multirow[t]{3}{*}{$\begin{array}{l}\text { Biodiversiteit en } \\
\text { landschap }\end{array}$} & GLMC9 & ES9 & $\begin{array}{l}\text { bloem/kruidenrijke randen } \\
\text { (met ES4) }\end{array}$ & $\begin{array}{l}\text { Minimaal } 5 \% \text { van het areaal aan niet-productieve } \\
\text { randen. Eventueel combineren met ES4: functie buf- } \\
\text { ferstroken }\end{array}$ & $650(300-1000)$ \\
\hline & GLMC9 & ES9 & $\begin{array}{l}\text { bloem/kruidenrijke randen } \\
\text { (met ES4) }\end{array}$ & $\begin{array}{l}\text { Minimaal } 7 \% \text { van het areaal aan niet-productieve } \\
\text { randen. Eventueel combineren met ES4: functie buf- } \\
\text { ferstroken }\end{array}$ & $650(300-1000)$ \\
\hline & GLMC10 & ES10 & $\begin{array}{l}\text { bio premie voor bio-boeren } \\
\text { binnen EHS }\end{array}$ & & 400 \\
\hline
\end{tabular}

De scenarios in de tabel zijn: Voor GLMC: O = optimaal, G = Goed, H =.huidig. Voor ES: B = Basis - Plus, $E L=$ Ecoscheme - licht, $E Z=$ Ecoscheme - zwaar en $K L=$ Kringlooplandbouw 